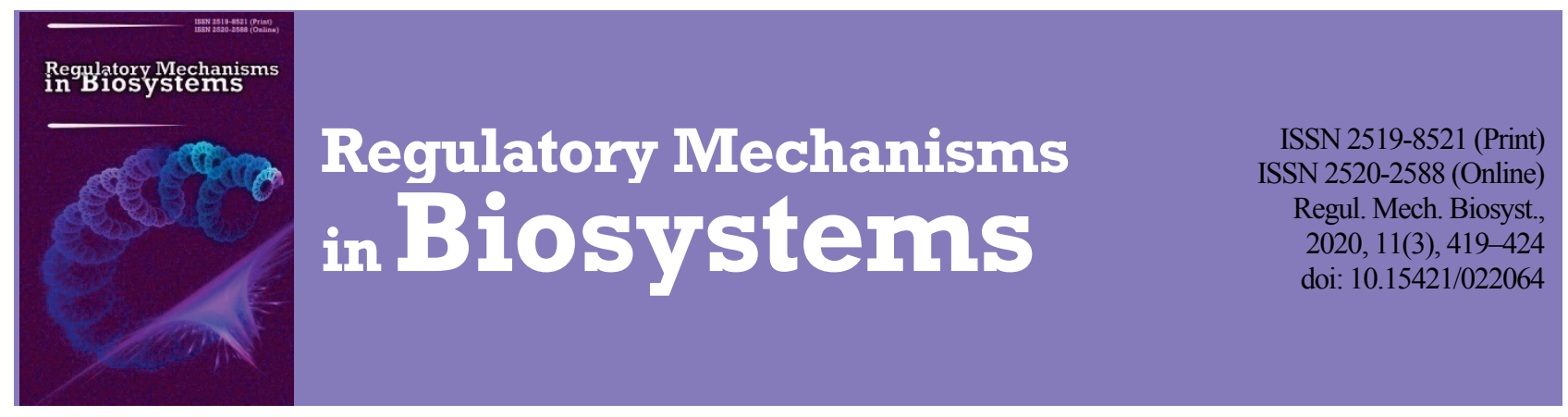

\title{
Antianemic action of the iron (IV) clathrochelate complexes
}

\author{
V. B. Dukhnitsky*, I. M. Derkach*, M. O. Plutenko**, I. O. Fritsky**, S. S. Derkach* \\ *National University of Life and Environmental Sciences of Ukraine, Kyiv, Ukraine \\ **Taras Shevchenko National University of Kyiv, Kyiv, Ukraine
}

Article info

Received 17.07.2020

Received in revised form

21.08.2020

Accepted 22.08.2020

National University of Life and Environmental Sciences of Ukraine, Heroyiv

Oboronyst., 15,

Kyiv, 03041, Ukraine.

Tel.: +38-066-772-41-94

E-mail:irina1215@ukr.net

Taras Shevchenko National

University of Kyiv,

Volodymyrska st., 64

Kyiv, 01601, Ukraine.

Tel.: +38-097-060-82-98.

E-mail:

plutenkom@gmail.com
Dukhnitsky, V. B., Derkach, I. M., Plutenko, M. O., Fritsky, I. O., \& Derkach, S. S. (2020). Antianemic action of the iron (IV) clathrochelate complexes. Regulatory Mechanisms in Biosystems, 11(3), 419-424. doi:10.15421/022064

Anemia is one of the most common non-contagious diseases of pigs. Modern antianemic drugs have several drawbacks, so finding new drugs is a pressing issue. We previously reported the results of preclinical studies of iron in rare high valence IV. This allowed us to determine, supplement, and generalize the data on clinical studies of the new drugs with the active substance iron (IV) clathrochelate. Therefore, we studied its antianemic effect on piglets. Experiments were carried out on piglets-analogues neonates, which were divided into three groups: control and two experimental groups. Piglets were kept with sows on suckling. For the purpose of prevention of iron deficiency anemia, the traditional solution of iron dextran was administered once intramuscularly to piglets of I control group. The aqueous solution of iron (IV) clathrochelate complexes was administered once intramuscularly to piglets of II experimental group. Iron (IV) clathrochelate complexes were dissolved in a solvent of rheopolyglucin and administered once intramuscularly to piglets of III experimental group. $1 \mathrm{~mL}$ of test solutions contained $100 \mathrm{mg}$ of active substance. The investigative material were the samples of blood and serum of piglets, their liver and spleen. The experiment lasted during a 30day period since the birth of the piglets. According to the results of the experiments, iron (IV) clatrochelate complexes which were dissolved in water for injection and rheopolyglucin had higher antianemic activity compared to the control. This is evidenced by the dynamics of probable changes in the number of erythrocytes, hemoglobin content and hematocrit, iron content in serum and its mass fraction in the blood, liver and spleen of piglets. The effectiveness of the action of iron (IV) clatrochelate complexes is demonstrated by the full supply of piglets with iron and its higher bioavailability.

Keywords: iron deficiency anemia; clinical studies; iron (IV); piglets; morphological parameters; biochemical indicators.

\section{Introduction}

The provision of means for the prevention, diagnosis of diseases and treatment of animals is an indispensable condition for successful livestock holding. In addition, it is well established that is should be based not only on massive investment from the state, but also on the high level of national scientific potential. Therefore, it is a highly relevant task to develop new effective drugs compared to existing ones.

Although anemia is a symptomatic complex which accompanies many pathological processes in the young, it is necessary to allocate precisely nutritional anemia (Bonkovsky \& Herbert, 1991; Camaschella, 2013; Knight \& Dilger, 2018), which causes significant economic losses on farms. This is a clinical hematological syndrome, which is as result of the shortage of iron, cuprum, cobalt, zinc, vitamins $\mathrm{C}$ and $\mathrm{B}_{12}$, which are essential for sustaining their organism (Walter et al., 1997; Svoboda et al., 2008; Wang et al., 2019). In conclusion it causes violations of the synthesis of hemoglobin and a decrease in the number of erythrocytes (Ganz, 2013; Leyshon et al., 2016; Shero et al., 2019). Many recent studies are devoted to hepcidin, a peptide hormone made in the liver, which is the principal regulator of systemic iron homeostasis. Synthesis of hepcidin is homeostatically increased by iron loading and decreased by anemia and hypoxia (Ganz \& Nemeth 2006, 2012; Nemeth \& Ganz, 2006; Sangkhae \& Nemeth, 2017).

In piglets, in contrast to young animals of other species, this type of anemia is an independent disease (Killip \& Bennett, 2008; Li et al., 2019). The newborn organism of the suckling pig has sufficient quantity of iron, which came through the placenta during prenatal development. However, they are the most immature of all farm animals. Their body weight does not reach $1 \%$ of the body mass of sows, and intensive growth is signifi- cantly ahead of the formation of blood-forming organs and the development of their functional activities. While piglets need iron in the amount $7-10 \mathrm{mg}$ ( $21 \mathrm{mg} / \mathrm{kg}$ of body mass gain), they receive only $1 \mathrm{mg}$ from colostrum or milk of sows. Up to 3 weeks of age, piglets will need iron from 114 to $200 \mathrm{mg}$, and with milk they receive only $23-24 \mathrm{mg}$ (Levchenko, 2005). The result above is that the hemocytopogenesis lags bihind the needs of the organism.

For the intensive pig farming prevention of this disease is especially necessary (Sjaastad et al., 1996; Batrakov et al., 2005; Kim et al., 2018). It was established that after treatment of animals who had this pathology the body is not able to realize own potential productivity, and the meat loses nutritional qualities and has restrictions on consumption. These animals present the pallor of mucous membranes, weight loss and immunity reduction, which in turn leads to infectious pathology and even death, which can increase by 60-70\% (Egeli et al., 1998; Klem et al., 2010; Cooper et al., 2014).

In modern veterinary medicine for the prevention and treatment of iron deficiency anemia of animals, iron (II) and iron (III) drugs are used: oral administration of iron salts (Maes et al., 2011; Svoboda et al., 2015) and parenteral administration of iron dextran drugs (Meier et al., 2011; Peña-Rosas et al., 2015; Pillay et al., 2018). Their disadvantage is a low percentage of suction that does not provide the necessary pharmacological effect. Maternal protein restriction depresses the duodenal expression of iron transporters and serum iron level in male weaning piglets (Ma et al., 2017). At the same time, the cost of iron dextran preparations is quite high.

So, now the pharmaceutical market of veterinary medicines faces the an important task of sufficiently ensuring the supply of effective national antianemic drugs and minimizing the country's dependence on foreign producers (Kalynovska, 2014; Derkach, 2017; Derkach et al., 2018). 
Scientists, in turn, should devise new veterinary drugs without disadvantages of existing ones (Diel et al., 2018; Dos Santos Vieira et al., 2018). Such drugs should not have a toxic effect, but on the contrary they should act on different levels of pathogenesis and provide effective and inexpensive prevention of iron deficiency anemia of piglets.

It is known that chelate complexes of microelements have an advantage over other drugs of the corresponding groups. This is due to the fact that they consist of metal ions and ligands, have high biological activity, and their digestibility is $95-100 \%$. As a result of the gradual rupture of chelate bonds, the drugs have a prolonged effect. After cleavage of microelements, some ligands are able to be used effectively by the body. This enables the dose of microelements to be reduced, which is very important for the use of heavy metals as active substances of drugs, and for solving certain problems (economic, environmental, biological, etc.).

We have studied a metal complex of iron in a form of clathrochelate and with rare valence IV. It is a macrobicyclic co-coordinate compound in which the metal ion is "packaged" in a nanocapsule, which hinders interaction with the overwhelming majority of reagents, in particular bioligands, and also screens metal from other environmental factors. For the first time the synthesis of iron (IV) clathrochelate it was reported as unique compounds of iron (IV), which are self-formed in aqueous solutions in the presence of oxigen of air (Tomyn et al., 2017). We conducted preclinical experiments of its acute and chronic toxicity, cumulative properties (Dukhnitsky et al., 2018, 2019, 2020). The results of our studies confirm the effectiveness of drugs with the active substance iron (IV) clathrochelate. Therefore, the objective of this study was to determine the effectiveness of the use of iron (IV) clatrochelate to prevent the iron deficiency anemia of pigs and assess effect of iron in new high valence IV on the dynamics of body weight of suckling piglets, hemoglobin content and morphological indicators of their blood, biochemical parameters of their blood serum, mass particles of iron in the blood, liver and spleen of piglets.

\section{Materials and methods}

Maintenance, feeding, care and all manipulations of the animals were conducted according to the European Convention for the Protection of Vertebrate Animals used for Experimental and other Scientific Purposes (Strasbourg, 1986) and "General Ethical Principles of Conducting Experiments on Animals" agreed at The First National Congress in Bioethics (Kyiv, 2001). The experiments were conducted in accordance with the principles of humanity set out in the directive of the European Community.

The experiment was carried out on 30 suckling piglets - hybrids of Great White and Landrace crossbred pigs during the period of their detention with sows. The research was conducted on a livestock farm (Kyiv region). According to the method of analogue-groups, three groups were formed: I control, II experimental, III experimental, each consisting of 10 animals. Duration of each experiment was 30 days.

For the purpose of prevention of iron deficiency anemia, on the second day of life the piglets were injected intramuscularly: traditional solution of iron (III) dextran - in the I control group; iron (IV) dissolved in rhepolipolyglukin - in the II experimental group; aqueous solution of iron (IV) - in the III experimental group. The solutions were administrated in dose of $2 \mathrm{~mL}$ for animals and $1 \mathrm{~mL}$ contains $100 \mathrm{mg}$ of the active substance.

Solvent rheopolyglukin is a plasma-type solution of destrin (polymer glucose), the pharmacological effect of which is manifested by the improvement of the rheological properties of blood, a decrease in its viscosity, recovery of microcirculatory blood, prevention and elimination of aggregation of uniform elements, normalization of arterial and venous circulation. The half-life period is 6 hours. It is excreted mainly by the kidneys: in the first 6 hours - about $60 \%$, in 24 hours $-70 \%$. The rest is supplied in the reticuloendothelial system and liver, where alpha-glucosidase is gradually split into glucose, but is not a source of carbohydrate power. In addition, rheopolyglukin contains sodium chloride, which after resorbescence is involved in metabolism and regulation of water metabolism. After the birth of the piglets, on the 7th, 14th and 30th days we determined changes in body weight. On the 7,14 , and 30 days of the life of the piglets we monitored hemoglobin content and morphological indices of blood, biochemical indices of the blood serum in accordance with the recognized methods. On the 30th day samples of blood, liver and spleen of piglets were sampled to determine their mass fraction of the iron.

The results were analyzed statistically using ANOVA. For all statistical calculations, the significance was considered as the value of $\mathrm{P}<0.05$. Correlation was calculated with Pearson's coefficient test.

\section{Results}

The change in body weight of animals compared to control is a very important indicator. Its deviation indicates the degree of damage to the body. Changes in body weight are especially important for young animals. As the age of the animal increases, the weight gain becomes lower.

We found that the dynamic of changes in body weight of piglets in the control and experimental groups differs during the experimental period. But on the 30th day of the experiment the body weight of piglets of I control and III experimental was the same, and the body weight of piglets of the II experimental group was the highest (Table 1).

\section{Table 1}

Change in the body weight (g) of piglets under the influence of iron (III) and iron (IV) $(x \pm S E, n=10)$

\begin{tabular}{lccc}
\hline \multicolumn{1}{c}{ Day of research } & Control & $\begin{array}{c}\text { Iron(IV) } \\
\text { clatrochelate }+ \\
\text { rheopolyglukin }\end{array}$ & $\begin{array}{c}\text { Iron(IV) } \\
\text { clatrochelate+ } \\
\text { aqua for injection }\end{array}$ \\
\hline Before the use of iron & $1795 \pm 31$ & $1788 \pm 26$ & $1779 \pm 60$ \\
7th & $2950 \pm 39$ & $3526 \pm 67^{* *}$ & $3680 \pm 67^{* *}$ \\
14th & $3627 \pm 53$ & $3920 \pm 143$ & $3892 \pm 33^{* *}$ \\
30th & $6500 \pm 164$ & $6683 \pm 48$ & $6500 \pm 47$ \\
\hline
\end{tabular}

Note: control - I control group, iron (IV) clatrochelate + rheopolyglukin - II experimental group, iron (IV) clathrochelate + aqua for injection - III experimental group; $*_{-} \mathrm{P}<0.05,{ }^{*}-\mathrm{P}<0.01-$ differences are likely to be in relation to the control group.

Therefore, the body weight of piglets in II experimental and III experimental groups on the 7th day (after using the test substance) was higher than in the control by $20 \%$ and $25 \%$; on the 14 th day - by $8 \%$ and $7 \%$ respectively. However, after 30 days the body weight of piglets of the III experimental group did not differ from the body weight of piglets of I control group and the body weight of piglets of II experimental group was higher than in the control group by $3 \%$ appropriately.

The blood system is one of the most mobile systems and responds quickly to changes in homeostasis of body. This is especially important for newborn piglets with "physiological" iron deficiency in the first days of life. Morphological parameters of the blood of piglets of the experimental groups were compared with the control. We analyzed the dynamics of changes in erythrocyte count, content of hemoglobin and indicator hematocrit (Table 2). This finding is supported by the fact that the concentration of hemoglobin in the blood is directly dependent on the number of red blood cells (Khariv, 2013; Grabovskyi, 2014). From the data shown in Table 2, it follows that on the 14th day after the use of iron (IV) in the blood of piglets of the II experimental group, the number of erythrocytes, hemoglobin and hematocrit increased by 1.7, 1.3, 1.1 $(\mathrm{P}<0.05, \mathrm{P}<0.01)$ times, respectively, and in the blood of piglets of the third experimental group these indicators increased by 1.7, 1.6, $1.1(\mathrm{P}<0.01)$ times, respectively, compared to the control. The research period (14 days) is characterized by the fact that the piglets' body has already used the reserve of iron (up to 7 days), and its receipt with mother's milk satisfies the needs of the piglets' body only by $10-15 \%$. Therefore, the use of iron-containing drugs based on iron (IV) clathrochelate prevented the development of erythrocytopenia and hypohemoglobinemia as a result of inhibition of hemocytopoietic function of the bone marrow in iron deficiency.

At the 30th day the amount of erythrocytes, content of hemoglobin and hematocrit in the blood of piglets of II experimental group were higher than in animals of the control group, and in the blood of piglets of III experimental group almost did not change compared to control.

The dynamics of probable changes $(\mathrm{P}<0.01, \mathrm{P}<0.001)$ of indicators $\mathrm{MCV}, \mathrm{MCH}$ and $\mathrm{MCHC}$ complement the described changes and indicate a high prophylactic antianemic effect of iron (IV) clathrochelate which is dissolved in solvents such as water for injection and rheopolyglukin. On the 14th day after the use of drugs of iron (IV) the number of leuko- 
cytes increased in $1.3(\mathrm{P}<0.05)$ times in the blood of piglets of the II experimental group and by $1.6(\mathrm{P}<0.01)$ times in the blood of piglets III experimental group compared to control. At 30th day this figure was almost no different from the control.

According to the results of the experiments, indicators PLT and MPV in piglets of the experimental groups did not change significantly for 30 days. At the same time, the ESR in piglets of both experimental groups was in 1.2-1.3 times lower than the control during the experimental period. Under the influence of preparations of iron (IV) clathrochelate, the leukogram of blood of piglets was characterized by significant changes (Table 3). It should be noted that on the 14th and 30th day of the research the dynamics of the number of band cells and segmented granular cells nucleus in the blood of piglets of experimental groups differed from control. In particular, the number of band neutrophils was lower in the blood of piglets of the II experimental group by 2.2 and $2.6(\mathrm{P}<0.01)$, respec- tively, and in blood of piglets of the III research group - by 2.6 and 3.3 (P $<0.05, \mathrm{P}<0.01)$, respectively, compared to I control group. The amount of segmented neutrophils in the blood of piglets of both experimental groups was conversely slightly higher than in control.

The amount of monocytes in the blood of piglets of II and III experimental groups for 14 days had decreased in 2.0 and $3.0(\mathrm{P}<0.05)$ times, respectively, compared with the control. And on the 30th day of experiment in the blood of piglets of II experimental group this indicator did not differ from the control. However, in the blood of piglets of III experimental group the amount of monocytes was lower. The number of lymphocytes and eosinophils in the blood of piglets of both II and III experimental groups almost did not differ from the indicators of piglets of I control group. Basophils, promyelocytes, myelocytes, methomilocytes, and plasma cells were not detected in the blood of animals during the experiment.

Table 2

Hemoglobin content and morphological indicators of blood of piglets under the influence of iron (III) and iron (IV) $(x \pm S E, n=10)$

\begin{tabular}{|c|c|c|c|c|}
\hline Indicator & Day of research & Control & $\begin{array}{l}\text { Iron (IV) clathrochelate + } \\
\text { rheopolyglukin }\end{array}$ & $\begin{array}{l}\text { Iron (IV) clathrochelate }+ \\
\text { aqua for injection }\end{array}$ \\
\hline \multirow{2}{*}{ Erythrocytes, $10^{12} / \mathrm{L}$} & 14th & $4.04 \pm 0.57$ & $6.74 \pm 0.07 * *$ & $6.56 \pm 0.03^{* *}$ \\
\hline & 30th & $6.86 \pm 0.09$ & $7.54 \pm 0.07 * *$ & $6.93 \pm 0.07$ \\
\hline \multirow{2}{*}{$\mathrm{MCV}$ (mean erythrocytes volume), $\mu \mathrm{m}^{3}$} & 14th & $62.9 \pm 0.3$ & $67.1 \pm 1.0^{*}$ & $64.2 \pm 0.3$ \\
\hline & 30th & $58.6 \pm 0.7$ & $62.2 \pm 0.8^{*}$ & $62.0 \pm 0.8$ \\
\hline \multirow{2}{*}{ RDW (red blood cell distribution width), \% } & 14th & $14.69 \pm 0.08$ & $15.27 \pm 0.19$ & $15.21 \pm 0.08^{* *}$ \\
\hline & 30th & $13.25 \pm 0.14$ & $13.60 \pm 0.05$ & $13.22 \pm 0.03$ \\
\hline \multirow{2}{*}{ Hemoglobin, g/L } & 14th & $79.6 \pm 1.0$ & $102.0 \pm 6.0^{*}$ & $123.5 \pm 0.6^{* *}$ \\
\hline & 30th & $121.6 \pm 0.7$ & $132.0 \pm 0.5^{* *}$ & $127.0 \pm 0.5^{* *}$ \\
\hline \multirow{2}{*}{$\mathrm{MCH}$ (mean corpuscular haemoglobin), pg } & 14th & $18.7 \pm 0.1$ & $19.2 \pm 0.5$ & $18.4 \pm 0.1^{*}$ \\
\hline & 30th & $17.2 \pm 0.1$ & $17.9 \pm 0.1 * *$ & $17.6 \pm 0.2$ \\
\hline \multirow{2}{*}{ MCHC (mean corpuscular hemoglobin concentration), $\%$} & 14th & $29.5 \pm 0.1$ & $28.7 \pm 0.1 * *$ & $28.6 \pm 0.2$ \\
\hline & 30th & $29.3 \pm 0.2$ & $29.7 \pm 0.3$ & $29.1 \pm 0.1$ \\
\hline \multirow{2}{*}{ Hematocrit, vol\% } & 14th & $37.5 \pm 1.0$ & $42.8 \pm 1.4^{* *}$ & $41.5 \pm 0.5^{* *}$ \\
\hline & 30th & $42.0 \pm 0.4$ & $45.9 \pm 0.4^{* *}$ & $42.7 \pm 0.2$ \\
\hline \multirow{2}{*}{ Leukocytes, $10^{9} / \mathrm{L}$} & 14th & $8.0 \pm 0.4$ & $10.0 \pm 0.5^{*}$ & $12.6 \pm 0.5^{* *}$ \\
\hline & 30th & $10.6 \pm 1.0$ & $11.6 \pm 0.5$ & $13.3 \pm 0.7^{*}$ \\
\hline \multirow{2}{*}{ Plateles, $10^{3} / \mathrm{mm}^{3}$} & 14th & $419.0 \pm 4.2$ & $427.9 \pm 10.3$ & $464.2 \pm 4.5^{* *}$ \\
\hline & 30th & $458.4 \pm 2.0$ & $441.4 \pm 10.9$ & $468.7 \pm 6.1^{*}$ \\
\hline \multirow{2}{*}{ MPV (mean platelet volume), $\mu \mathrm{m}^{3}$} & 14th & $9.0 \pm 0.47$ & $9.08 \pm 0.17$ & $8.66 \pm 0.13$ \\
\hline & 30th & $9.68 \pm 0.43$ & $9.82 \pm 0.11$ & $10.19 \pm 0.34$ \\
\hline \multirow{2}{*}{ ESR (erythrocyte sedimentation rate) } & 14th & $4.0 \pm 0.15$ & $3.3 \pm 0.15^{*}$ & $3.0 \pm 0.21^{*}$ \\
\hline & 30 th & $4.0 \pm 0.14$ & $3.0 \pm 0.15^{* *}$ & $3.5 \pm 0.16^{*}$ \\
\hline
\end{tabular}

Note: control - I control group, iron (IV) clathrochelate + rheopolyglukin - II experimental group, iron (IV) clathrochelate + aqua for injection - III experimental group; * $-\mathrm{P}<$ $0.05, * *-\mathrm{P}<0.01-$ differences are likely to be in relation to the control group.

Table 3

Leukogram (\%) of blood of piglets under the influence of iron (III) and iron (IV) $(x \pm S E, n=10)$

\begin{tabular}{|c|c|c|c|c|}
\hline Indicator & Day of research & Control & $\begin{array}{l}\text { Iron (IV) clathrochelate + } \\
\text { rheopolyglukin }\end{array}$ & $\begin{array}{l}\text { Iron (IV) clathrochelate + } \\
\text { aqua for injection }\end{array}$ \\
\hline \multirow{2}{*}{ Basophils } & 14th & 0 & 0 & 0 \\
\hline & 30th & 0 & 0 & 0 \\
\hline \multirow{2}{*}{ Eosinophils } & 14th & $4.03 \pm 0.33$ & $5.12 \pm 0.82$ & $4.51 \pm 0.42$ \\
\hline & 30th & $5.10 \pm 0.98$ & $4.70 \pm 0.31$ & $5.52 \pm 0.41$ \\
\hline \multirow{2}{*}{ Band cells } & 14th & $5.11 \pm 0.23$ & $2.31 \pm 0.25^{* *}$ & $3.90 \pm 0.21 *$ \\
\hline & 30th & $4.11 \pm 0.22$ & $1.49 \pm 0.15^{* *}$ & $1.21 \pm 0.14 * *$ \\
\hline \multirow{2}{*}{ Segmented granular cells nucleus } & 14th & $46.2 \pm 0.5$ & $48.7 \pm 0.3$ & $49.2 \pm 0.3^{* *}$ \\
\hline & 30th & $55.9 \pm 1.3$ & $61.1 \pm 0.8^{*}$ & $55.1 \pm 0.3$ \\
\hline \multirow{2}{*}{ Lymphocytes } & 14th & $39.9 \pm 1.4$ & $40.1 \pm 1.3$ & $43.1 \pm 0.5$ \\
\hline & 30th & $32.1 \pm 0.5$ & $29.0 \pm 0.3^{* *}$ & $37.4 \pm 0.5^{* *}$ \\
\hline \multirow{2}{*}{ Monocytes } & 14th & $6.03 \pm 0.26$ & $3.04 \pm 0.49^{*}$ & $3.21 \pm 0.42 *$ \\
\hline & 30th & $5.02 \pm 0.49$ & $5.03 \pm 0.26$ & $2.02 \pm 0.32 * *$ \\
\hline
\end{tabular}

Note: control - I control group, iron (IV) clathrochelate + rheopolyglukin - II experimental group, iron (IV) clathrochelate + aqua for injection - III experimental group; * $-\mathrm{P}<$ $0.05, * *-\mathrm{P}<0.01-$ differences are likely to be in relation to the control group.

The underlying of biological action of chemical factors is the disturbance of a number of biochemical processes. The main importance of this are structural and metabolic complexes, which are associated with the synthesis of protein, bioenergetic metabolism of chemical compounds and the process of catabolism. Biochemical investigations include tests of indicators that reflect the functional state of individual organs (Fig. 1).

The results of this tests on piglets showed that on the 7th, 14th and 30th days iron content in the blood serum of II experimental group was higher by 1.7, 2.3, $1.5(\mathrm{P}<0.01)$ times respectively, and iron content in the blood serum of piglets of III experimental group - by 1.5, 1.4, $1.2(\mathrm{P}<$ $0.05, \mathrm{P}<0.01)$ once, respectively, compared to control. The high level of iron in the blood serum of piglets of II experimental group is indicative of fact that the iron (IV) clathrochelate which dissolved in reopolipolyglukin creates its reserve in blood serum for a long period of time. Considering the changes in the dynamics of the other biochemical parameters of blood serum (Table 4) for 30 days important information was obtained about the metabolism in the body of piglets under the influence of iron in the valence III and IV. 


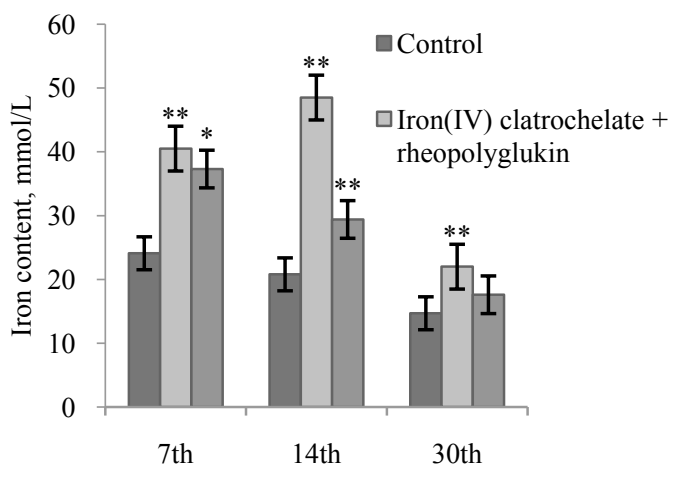

Fig. 1. The iron content in blood serum of piglets under the influence of iron (III, IV): control - I control group, iron (IV) clathrochelate + rheopolyglukin - II experimental group, iron (IV) clathrochelate + aqua for injection-III experimental group; ${ }^{*}-\mathrm{P}<0.05,{ }^{* *}-\mathrm{P}<0.01$ - differenc-

are likely to be in relation to the control group; $\mathrm{x} \pm \mathrm{SE}, \mathrm{n}=10$

Table 4

Biochemical indicators of blood serum of piglets under the influence of iron (III) and iron (IV) $(\mathrm{x} \pm \mathrm{SE}, \mathrm{n}=10)$

\begin{tabular}{|c|c|c|c|c|}
\hline Indicator & $\begin{array}{l}\text { Day of } \\
\text { research }\end{array}$ & Control & $\begin{array}{l}\text { Iron (IV) } \\
\text { clathrochelate + } \\
\text { rheopolyglukin }\end{array}$ & $\begin{array}{c}\text { Iron (IV) } \\
\text { clathrochelate + } \\
\text { aqua for injection }\end{array}$ \\
\hline \multirow{3}{*}{ Total protein, $\mathrm{g} / \mathrm{L}$} & 7 th & $45.8 \pm 0.3$ & $47.1 \pm 0.5$ & $44.6 \pm 1.6$ \\
\hline & 14th & $44.6 \pm 1.2$ & $50.5 \pm 0.6^{* *}$ & $52.7 \pm 0.8^{* *}$ \\
\hline & 30th & $47.1 \pm 0.5$ & $48.7 \pm 0.5$ & $50.4 \pm 0.3^{* *}$ \\
\hline \multirow{3}{*}{ Albumins, $\%$} & 7 th & $53.2 \pm 0.8$ & $53.5 \pm 0.7$ & $54.4 \pm 0.2$ \\
\hline & 14th & $54.7 \pm 0.5$ & $62.4 \pm 0.7 * *$ & $52.1 \pm 0.3^{* *}$ \\
\hline & 30th & $58.1 \pm 1.0$ & $57.4 \pm 0.9$ & $57.9 \pm 0.2$ \\
\hline \multirow{3}{*}{$\alpha_{1}$-globulinis $\%$} & 7 th & $2.40 \pm 0.13$ & $3.0 \pm 0.09^{* *}$ & $2.60 \pm 0.08$ \\
\hline & 14th & $2.20 \pm 0.15$ & $2.10 \pm 0.11$ & $1.10 \pm 0.02$ \\
\hline & 30th & $1.90 \pm 0.09$ & $2.90 \pm 0.08^{* *}$ & $1.70 \pm 0.16^{* *}$ \\
\hline \multirow{3}{*}{$\alpha_{2}$-globulinis, $\%$} & 7 th & $10.67 \pm 0.59$ & $8.95 \pm 0.68$ & $11.16 \pm 0.73$ \\
\hline & 14th & $10.16 \pm 0.34$ & $12.41 \pm 0.39 * *$ & $13.19 \pm 0.12^{* *}$ \\
\hline & 30th & $9.91 \pm 0.28$ & $11.29 \pm 0.52$ & $9.23 \pm 0.02$ \\
\hline \multirow{3}{*}{$\beta$-globulinis, $\%$} & 7th & $16.78 \pm 0.26$ & $12.76 \pm 0.67 * *$ & $16.28 \pm 0.12$ \\
\hline & 14th & $14.04 \pm 0.47$ & $15.25 \pm 0.17^{*}$ & $17.19 \pm 0.14^{* *}$ \\
\hline & 30th & $12.18 \pm 0.37$ & $15.56 \pm 0.18^{* *}$ & $17.17 \pm 0.13^{* *}$ \\
\hline \multirow{3}{*}{$\gamma$-globulinis, $\%$} & 7 th & & $21.32 \pm 0.29 *$ & $15.08 \pm 0.51$ \\
\hline & 14th & $16.47 \pm 0.42$ & $17.12 \pm 1.28$ & $15.51 \pm 0.13$ \\
\hline & 30th & $16.56 \pm 0.39$ & $12.81 \pm 0.72 * *$ & $15.48 \pm 0.14^{* *}$ \\
\hline \multirow{3}{*}{ Coefficient, $\mathrm{A} / \mathrm{G}$} & 7th & $1.11 \pm 0.04$ & $1.20 \pm 0.03$ & $1.20 \pm 0.01$ \\
\hline & 14th & $1.32 \pm 0.04$ & $1.60 \pm 0.06^{* *}$ & $1.10 \pm 0.01^{* *}$ \\
\hline & 30th & $1.51 \pm 0.06$ & $1.40 \pm 0.05$ & $1.10 \pm 0.01$ \\
\hline \multirow{3}{*}{ Glucose, $\mathrm{mmol} / \mathrm{L}$} & 7 th & $7.50 \pm 0.12$ & $7.38 \pm 0.35$ & $6.80 \pm 0.29$ \\
\hline & 14th & $6.80 \pm 0.19$ & $7.02 \pm 0.22$ & $6.30 \pm 0.11$ \\
\hline & 30th & $6.40 \pm 0.11$ & $6.10 \pm 0.20$ & $5.40 \pm 0.20^{* *}$ \\
\hline \multirow{3}{*}{$\begin{array}{l}\text { Inorganic } \\
\text { phosphorus, } \\
\mathrm{mmol} / \mathrm{L}\end{array}$} & 7th & $3.80 \pm 0.06$ & $3.90 \pm 0.11$ & $3.80 \pm 0.15$ \\
\hline & 14th & $3.40 \pm 0.12$ & $2.70 \pm 0.07 * *$ & $2.60 \pm 0.03 * *$ \\
\hline & 30th & $2.60 \pm 0.14$ & $3.00 \pm 0.10$ & $3.30 \pm 0.01 *$ \\
\hline \multirow{3}{*}{$\begin{array}{l}\text { Total calcium, } \\
\mathrm{mmol} / \mathrm{L}\end{array}$} & 7 th & $2.80 \pm 0.06$ & $2.80 \pm 0.02$ & $3.11 \pm 0.04 * *$ \\
\hline & 14th & $2.50 \pm 0.11$ & $2.70 \pm 0.04$ & $2.90 \pm 0.08^{*}$ \\
\hline & 30th & $2.50 \pm 0.14$ & $2.60 \pm 0.05$ & $2.70 \pm 0.03$ \\
\hline
\end{tabular}

Note: control - I control group, iron (IV) clathrochelate + rheopolyglukin - II experimental group, iron (IV) clathrochelate + aqua for injection - III experimental group; $*_{-} \mathrm{P}<0.05,{ }^{* *}-\mathrm{P}<0.01-$ differences are likely to be in relation to the control group.

It was been shown in this experiment that on 7 th day probable changes of some rates were only in the blood serum of piglets of II experimental group, which received iron (IV) clathrochelate in combination with rhepolyglukin. In particular, content of total protein, $\alpha_{1^{-}}, \beta$ - and $\gamma$ globulins increased. After 14 days, the probable increase of levels of total protein, $\alpha_{2^{-}}, \beta$ - and $\gamma$-globulins were found in blood serum piglets of both experimental groups. The albumin content in blood serum of II experimental group was probably increased by $14 \%$, however in blood serum of III experimental group this indicator decreased by 5\%. After 30 days levels of total protein, $\alpha_{2}$, $\beta$-globulins in blood serum of piglets of both experimental groups were probably higher compared to control. The content $\gamma$-globulins in blood serum piglets of both research groups was lower than control. At the same time, the levels of glucose, total calcium and inorganic phosphorus in the blood serum of piglets of both experimental groups were not substantially different from control during our experiment. Also our studies have established that the iron content in the blood, liver and spleen of experimental piglets depended on the drug used (Fig. 2).

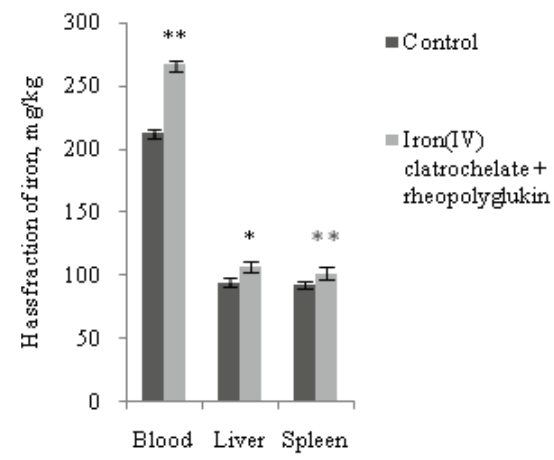

Fig. 2. Mass fraction of iron in of blood, liver and spleen of piglets under the influence of iron (III, IV) drugs: control - I control group, iron (IV) clathrochelate + rheopolyglukin - II experimental group; ${ }_{*}{ }_{-} \mathrm{P}<0.05,{ }^{* *}-\mathrm{P}<0.01-$ differences are likely to be in relation to I the control group; $\mathrm{x} \pm \mathrm{SE}, \mathrm{n}=5$

According to the results of the experiments, on the 30th day of experiment the iron content in of blood, liver and spleen of piglets of II experimental group (used solution of combination iron (IV) with rheopolyglukin) was higher by 25 and $10 \%$ respectively, compared to I control group (used solution of combination iron (III) with dextran).

\section{Discussion}

Improving the prevention of iron deficiency anemia of swine as one of the most common noncontagious diseases of animals of this type does not lose its relevance all over the world. Recent literature confirms this. To better assess the iron status scientists have developed a novel mass spectrometry assay to quantify pig plasma levels of the iron-regulatory peptide hormone hepcidin-25, which is predominantly secreted by the liver and acts as a negative regulator of iron absorption and reutilization. Their data show that plasma hepcidin-25 levels can guide optimal dosing of iron treatment and pave the way for mixed supplementation of piglets starting with intramuscular injection of iron dextran followed by dietary supplementation, which could be efficient under conditions of very low plasma hepcidin-25 level (Starzyński et al., 2013). However, according to data from the literature, some authors (Lipiński et al., 2013) state that the progress has been made in uncovering the molecular mechanisms of fetal iron homeostasis, introducing the molecules involved in iron transfer across the placenta, and briefly explain the role of iron transporters in the absorption of this microelement during early postnatal life. Also new perspectives on the regulation of iron absorption via cellular zinc concentrations are studied (Knez et al., 2017).

It should be noted that the question of the iron deficiency anemia can be studied both in relation to sows and in relation to fetuses/suckling piglets. Furthermore, stillbirth rates might be reduced by increasing the $\mathrm{HbC}$ of the sow. Some studies have indicated that high piglet blood hemoglobin concentration $(\mathrm{HbC})$ at birth lead to better performance later in life. Such experiments may be in different directions: the primary objective of this study was to investigate the association between sow and piglet blood $\mathrm{HbC}$ at farrowing; a secondary objective was to investigate the relationship between sow $\mathrm{HbC}$ and probability of stillbirths. Intramuscular injection of two doses of $2500 \mathrm{mg}$ iron two weeks apart at mid-gestation did neither change hematological variables in sows nor in the piglets at farrowing. Similarly, iron treatment did not reduce the probability of stillbirths among the offspring. Much of this research has demonstrated that the sows recruited in study tolerated the iron injections well. Further characterization of erythrocytes did not indicate that sows had iron deficiency anemia at baseline (Bhattarai et al., 2019). The result of those authors 
indicate that $\mathrm{HbC}$ in newborn piglets may be increased by increasing the sow $\mathrm{HbC}$.

The results of our experiments coincide with the data (Lipinski et al., 2010; Lipinski et al., 2013; Chen et al., 2019) provided by other researchers and demonstrate that the using newborn piglets as a model for iron deficiency is a convenient animal model for performing preclinical studies. As we know, parenteral iron supplementation by a unique intramuscular administration of large amounts of iron dextran is current practice for the treatment of iron deficiency anemia in piglets. However, the results of our experiments concur with the conclusions of other authors (Szudzik et al., 2018; Chen et al., 2019; Szudzik et al., 2020) that iron supplementation is necessary to avoid iron deficiency anemia in the neonatal period.

Scientists have compared the effects of routinely used protocol by intramuscular injection of high amount of iron dextran and a modified strategy by split iron supplementation with reduced amounts of iron. The results showed that split iron supplementation efficiently improved hematological status of piglets and attenuated the induction of hepcidin expression, which resulted in the recovery of piglets from iron deficiency and the increase of iron utilization. With this aim, the objective of another study was to develop an encapsulated iron supplement for oral ingestion and to determine its effect on the iron nutrition status of suckling pigs (Churio et al., 2018).

We determined that iron in new high valence IV has antianemic action in the body of suckling piglets, which is important to their life in contrast to young animals of other species. We demonstrated that increase of body weight of pigs of II and III experimental groups in comparison with the control 7 days after the administration of solutions of iron (IV) by 576 and $730 \mathrm{~g}$; after 14 days - by 293 and $265 \mathrm{~g}$, respectively, testifies to activation of synthesis processes in their body. Under the influence of iron (IV) clathrochelate hemocytopoeis was stimulated in piglets of both experimental groups, which indicates that it is probably higher in content of hemoglobin, hematocrit and the number of erythrocytes in their blood, compared to the indicators of piglets of I control group. After the use of drugs of the iron (IV) clathrochelate iron content in the blood serum of piglets of II and III experimental groups was higher than in the control by $1.5-2.3$ and 1.2-1.5, respectively. High levels of iron in blood serum of piglets of the II experimental group for 30 days testifies to the ability of iron (IV) clathrochelate which was dissolved in the rheopolyglukin to create the stock of iron for a long time. The high bioavailability of the iron (IV) clathrochelate which dissolved in rheopolyglukin, compared to the dextran drugs of iron, is confirmed by a high iron content in the blood, liver and spleen of piglets in both experimental groups by 25 and $10 \%$, respectively.

\section{Conclusion}

Therefore, we demonstrated the higher antianemic efficiency of iron (IV) drugs compared to the traditional iron dextran drugs. We demonstrated the data of change of body weight, morphological and biochemical parameters of blood and blood serum of suckling piglets during the period of 30 days. Our results indicate that iron (IV) clathrochelate complexes which were dissolved in water for injection and rheopolyglucin had higher antianemic activity compared to the control. In the background of the overall positive effect we showed similar dynamics of probable changes in the number of erythrocytes, hemoglobin content and hematocrit, iron content in serum and its mass fraction in the blood, liver and spleen of piglets too. The effectiveness of the action of iron (IV) clathrochelate complexes is demonstrated by the full supply of piglets with iron and its higher bioavailability.

\section{References}

Batrakov, A., Travkin, O., \& Jakovleva, E. (2005). Profilaktika alimentarnoj anemii u porosjat [Prevention of malignant anemia of piglets]. Veterinarija, 12, $44-45$ (in Russian).

Bhattarai, S., Framstad, T., \& Nielsen, J. P. (2019). Association between sow and piglet blood hemoglobin concentrations and stillbirth risk. Acta Veterinaria Scandinavica, 61(1), 61 .
Bhattarai, S., Framstad, T., \& Nielsen, J. P. (2019). Iron treatment of pregnant sows in a Danish herd without iron deficiency anemia did not improve sow and piglet hematology or stillbirth rate. Acta Veterinaria Scandinavica, 61(1), 60.

Bonkovsky, S., \& Herbert, L. (1991). Iron and the liver. The American Journal of the Medical Sciences, 301(1), 32-43.

Camaschella, C. (2013). Iron and hepcidin: A story of recycling and balance. Hematology. American Society of Hematology. Education Program, 2013(1), 1-8.

Chen, X., Zhang, X., Zhao, J., Tang, X., Wang, F., \& Du, H. (2019). Split iron supplementation is beneficial for newborn piglets. Biomedicine and Pharmacotherapy, 120, 109479.

Churio, O., Durán, E., Guzmán-Pino, S. A., \& Valenzuela, C. (2018). Use encapsulation technology to improve the efficiency of an iron oral supplement to prevent anemia in suckling pigs. Animals, 9(1), 1.

Cooper, C. A., Moraes, L. E., Murray, J. D., \& Owens, S. D. (2014). Hematologic and biochemical reference intervals for specific pathogen free 6-week-old Hampshire-Yorkshire crossbred pigs. Journal of Animal Science and Biotechnology, 5(1), 5 .

Derkach, I. (2017). Suchasni tendentsii na vitchyznianomu rynku ferumvmisnykh preparativ dlia tvaryn [Modern trends of the Ukrainian market of ironcontaining products for animals]. Naukovyi Visnyk Lvivskoho Natsionalnoho Universytetu Veterynarnoi Medytsyny ta Biotekhnolohii Imeni S. Z. Hzhytskoho, 19(78), 23-25 (in Ukrainian).

Derkach, I., Derkach, S., \& Sotnichenko, I. (2018). Ferum u skladi kormovykh dobavok, hotovykh kormiv ta premiksiv na farmatsevtychnomu rynku v Ukraini [Iron in the content of feed additives, prepared feeds and premixes on the pharmaceutical market in Ukraine]. Naukovyi Visnyk Lvivskoho Natsionalnoho Universytetu Veterynarnoi Medytsyny ta Biotekhnolohii Imeni S. Z. Hzhytskoho, 20(83), 290-294 (in Ukrainian).

Diel, J., Bertoldi, A., \& Pizzol, T. (2018). Iron salts and vitamins: Use, purchase and sources of obtainment among children in Brazil. Cad Saude Publica, 34(9), e00133317.

Dos Santos Vieira, D. A., Hermes Sales, C., Galvão Cesar, C. L., Marchioni, D. M., \& Fisberg, R. M. (2018). Influence of haem, non-haem, and total iron intake on metabolic syndrome and its components: A population-based study. Nutrients, 10(3), 314.

Dukhnitsky, V. B., Derkach, I. M., Derkach, S. S., Plutenko, M. O., \& Fritsky, I. O. (2019). Influence of iron (IV) clathrochelate complex on quail blood parameters and weight characteristics. Ukrainian Journal of Ecology, 9(3), 126-131.

Dukhnitsky, V. B., Derkach, I. M., Plutenko, M. O., Fritsky, I. O., \& Derkach, S. S. (2018). Vyznachennia parametriv hostroi toksychnosti ferumu (IV) na bilykh myshakh [Determination of the accumulative toxicity parameters of iron (IV) on white mice]. Ukrainian Journal of Ecology, 8(2), 308-312 (in Ukrainian).

Dukhnitsky, V. B., Kalachniuk, L. H., Derkach, I. M., Derkach, S. S., Plutenko, M. O., \& Fritsky, I. O. (2020). Iron (IV) hexahydrazide clathrochelate complexes: The chronic toxicity study. Ukrainian Journal of Ecology, 9(3), 18-23.

Egeli, A. K., Framstad, T., \& Morberg, H. (1998). Clinical biochemistry, haematology and body weight in piglets. Acta Veterinaria Scandinavica, 39(3), 381-393.

Ganz, T. (2013). Systemic iron homeostasis. Physiological Reviews, 93(4), 17211741.

Ganz, T., \& Nemeth, E. (2006). Iron imports. IV. Hepcidin and regulation of body iron metabolism. American Journal of Physiology. Gastrointestinal and liver physiology, 290(2), G199-G203.

Ganz, T., \& Nemeth, E. (2012). Hepcidin and iron homeostasis. Biochimica et Biophysica Acta, 1823(9), 1434-1443.

Grabovskyi, S. S. (2014). Effect of natural immunomodulators influence on cellular immunity indices and cortisol level in rat's blood at pre-slaughter stress. Studia Biologica, 8(1), 93-102.

Kalynovska, L. (2014). Zareiestrovani v Ukraini preparaty dlia profilaktyky i likuvannia tvaryn pry anemii [Medicines which are registered in Ukraine for the prevention and treatment of animals with anemia]. Naukovo-Tekhnichnyi Biuleten Instytutu Biolohii Tvaryn i Derzhavnoho Naukovo-Doslidnoho Kontrolnoho Instytutu Veterynarnykh ta Kormovykh Dobavok, 15(1), 279-283 (in Ukrainian).

Khariv, I. I. (2013). Vplyv “Amprolinsylu” ta brovitakoktsydu na pokaznyky klitynnoho i humoralnoho imunitetu indykiv za eymeriozo-histomonoznoyi invaziyi [Influence of amprolissil and broth tacticide on indicators of cell and humoral immunity of turkey cocks under the emeritus-histomonous invasion]. Biolohiya Tvaryn, 15(4), 159-165.

Killip, S., Bennett, M. (2008). Iron deficiency anemia. American Family Physician, 78(8), 671-678.

Kim, J. C., Wilcock, P., \& Bedford, M. R. (2018). Iron status of piglets and impact of phytase superdosing on iron physiology: A review. Animal Feed Science and Technology, 235, 8-14.

Klem, T. B., Bleken, E., Morberg, H., Thoresen, S. I., \& Framstad, T. (2010). Hematologic and biochemical reference intervals for Norwegian crossbreed grower pigs. Veterinary Clinical Pathology, 39(2), 221-226. 
Knez, M., Graham, R. D., Welch, R. M., \& Stangoulis, J. C. (2017). New perspectives on the regulation of iron absorption via cellular zinc concentrations in humans. Critical Reviews in Food Science and Nutrition, 57(10), 2128-2143.

Knight, L. C., \& Dilger, R. N. (2018). Longitudinal effects of iron deficiency anemia and subsequent repletion on blood parameters and the rate and composition of growth in pigs. Nutrients, 10(5), 632.

Levchenko, V., Zajarnuk, V., Papchenko, I., Abdullaev, S., Bogatko, L., Kostenko, L., Sokoluk, V., Sharandak, V., \& Shulga, P. (2005). Khvoroby svynei [Diseases of pigs]. Bilotserkivskyi Derzhavnyi Ahrarnyi Universytet, Bila Tserkva (in Ukrainian).

Leyshon, B. J., Radlowski, E. C., Mudd, A. T., Steelman, A. J., \& Johnson, R. W. (2016). Postnatal iron deficiency alters brain development in piglets. The Journal of Nutrition, 146(7), 1420-1427.

Li, R., Wang, F., Zhang, Y., Li, C., Xia, C., Chen, H., Lu, X., \& Liu, F. (2019). Comparison of hematologic and biochemical reference values in specific-pathogenfree 1-month-old Yorkshire pigs and Yorkshire-Landrace crossbred pigs. Canadian Journal of Veterinary Research, 83(4), 285-290.

Lipinski, P., Starzyński, R. R., Canonne-Hergaux, F., Tudek, B., Oliński, R., Kowalczyk, P., Dziaman, T., Thibaudeau, O., Gralak, M. A., Smuda, E., Woliński, J., Usińska, A., \& Zabielski, R. (2010). Benefits and risks of iron supplementation in anemic neonatal pigs. The American Journal of Pathology, 177(3), 1233-1243.

Lipiński, P., Styś, A., \& Starzyński, R. R. (2013). Molecular insights into the regulation of iron metabolism during the prenatal and early postnatal periods. Cellular and Molecular Life Sciences, 70(1), 23-38.

Ma, W., Lu, J., Jiang, S., Cai, D., Pan, S., Jia, Y., \& Zhao, R. (2017). Maternal protein restriction depresses the duodenal expression of iron transporters and serum iron level in male weaning piglets. The British Journal of Nutrition, 117(7), 923-929.

Maes, D., Steyaert, M., Vanderhaeghe, C., López Rodríguez, A., de Jong, E., Del Pozo Sacristán, R., Vangroenweghe, F., \& Dewulf, J. (2011). Comparison of oral versus parenteral iron supplementation on the health and productivity of piglets. Veterinary Record, 19, 168-188.

Meier, T., Schropp, P., Pater, C., Leoni, A., Khov-Tran, V., \& Elford, P. (2011) Physicochemical and toxicological characterization of a new generic iron sucrose preparation. Arzneimittelforschung, 61(2), 112-119.

Miranda, M., \& Lawson, H. (2018). Ironing out the details: Untangling dietary iron and genetic background in diabetes. Nutrients, 10(10), 1437.
Nemeth, E., \& Ganz, T. (2006). Regulation of iron metabolism by hepcidin. Annual Review of Nutrition, 26, 323-342.

Peña-Rosas, J., De-Regil, L., Gomez Malave, H., Flores-Urrutia, M., \& Dowswell, T. (2015). Intermittent oral iron supplementation during pregnancy. Cochrane Database System Review, 10, SD009997.

Pillay, D., Wham, C., Moyes, S., Muru-Lanning, M., The, R., \& Kerse, N. (2018). Intakes, adequacy, and biomarker status of iron, folate, and vitamin $\mathrm{B}_{12}$ in māori and non-māori octogenarians: Life and living in advanced age: A cohort study in New Zealand (LiLACS NZ). Nutrients, 14, 10(8), 1090.

Sangkhae, V., \& Nemeth, E. (2017). Regulation of the iron homeostatic hormone hepcidin. Advances in Nutrition, 8(1), 126-136.

Shero, N., Fiset, S., Blakley, B., Jougleux, J. L., Surette, M. E., Thabet, M., \& Rioux, F. M. (2019). Impact of maternal iron deficiency on the auditory functions in the young and adult guinea pig. Nutritional Neuroscience, 22(6), 444 452

Sjaastad, O. V., Framstad, T., \& Blom, A. K. (1996). Effect of iron on erythropoietin production in anaemic piglets. Acta Veterinaria Scandinavica, 37(2), 133-138.

Starzyński, R. R., Laarakkers, C. M., Tjalsma, H., Swinkels, D. W., Pieszka, M., Styś, A., Mickiewicz, M., \& Lipiński, P. (2013). Iron supplementation in suckling piglets: How to correct iron deficiency anemia without affecting plasma hepcidin levels. PloS One, 8(5), e64022.

Svoboda, M., \& Drabek, J. (2005). Iron deficiency in suckling piglets: Etiology, clinical aspects and diagnosis. Folia Veterinaria, 49, 104-111.

Svoboda, M., \& Pískova, K. (2018). Oral iron administration in suckling piglets - a review. Acta Veterinaria Brno, 87(1), 77-83.

Szudzik, M., Lipiński, P., Jończy, A., Mazgaj, R., Pieszka, M., Kamyczek, M., Smuda, E., \& Starzyński, R. R. (2020). Long-term effect of split iron dextran/hemoglobin supplementation on erythrocyte and iron status, growth performance, carcass parameters, and meat quality of Polish large white and 990 line pigs. Biological Trace Element Research, 196(2), 472-480.

Szudzik, M., Starzyński, R. R., Jończy, A., Mazgaj, R., Lenartowicz, M., \& Lipiński, P. (2018). Iron supplementation in suckling piglets: An ostensibly easy therapy of neonatal iron deficiency anemia. Pharmaceuticals, 11(4), 128.

Tomyn, S., Shylin, S., Bykov, D., Ksenofontov, V., Gumienna-Kontecka, E., Bon V., \& Fritsky I. (2017). Indefinitely stable iron (IV) cage complexes formed in water by air oxidation. Nature Communications, $8,1-8$.

Walter, T., Olivares, M., Pizarro, F., \& Muñoz, C. (1997). Iron, anemia, and infection. Nutrition Reviews, 55(4), 111-124.

Wang, X., Garrick, M. D., \& Collins, J. F. (2019). Animal models of normal and disturbed iron and copper metabolism. The Journal of Nutrition, 149(12), 2085-2100. 